\title{
Ubá, Belenenses
}

\author{
Eduardo Frigatti
}

Uniwersytet Marii Curie-Skłodowskiej (UMCS-Lublin) | Polônia

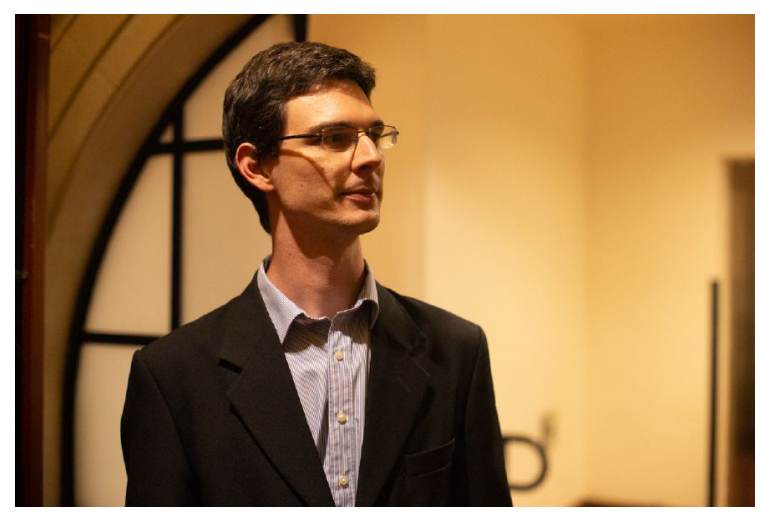

Dr. Eduardo Frigatti studied composition with Krzysztof Penderecki, Rodrigo Lima, Maurício Dottori and Silvio Ferraz. He has completed his $\mathrm{PhD}$ at USP, São Paulo. His works have been performed internationally as well as locally: Sala São Paulo, NOSPR (Polish National Radio Symphony Orchestra), at the International Festival of Krakow Composers in Poland, MusLAB Festival in Mexico, Festival Contrasti-Trento in Italy and at 8th International Competition of Duets with Harp, Poland (2019); at several festivals in Brazil (Panorama da Musica Brasileira, Bienal Música Hoje, Festival Internacional de Londrina, Oficina de Música de Curitiba), Capela Santa Maria (Curitiba). Several of his compositions were awarded, such as: first prize in the III Composition Competition of the Music Biennial Today (2015) for his work Campina de Vidro (for string orchestra and piano); an award in the 1st Composition Competition of the Edino Krieger Contemporary Music Festival (2017) for his composition Morriña (a string quartet); second prize in $1^{\text {st }}$ National Competition for Clarinet Solo Composition for his work Moods (2018); third prize in the 8th International Competition of Duets with Harp, Poland (2019), for his work Armorial (for violin and harp).

E-mail: edufrigatti@yahoo.com.br

Website: https://eduardofrigatticomposer.wordpress.com/ https://www.facebook.com/EduardoFrigattiComposer

ORCID: https://orcid.org/0000-0001-9468-0657 
I n 2013, I participated in the IX International Symposium on Cognition and Musical Arts, in Belém do Pará, Brazil. Between the debates and the concerts, there is always some opportunity to get to know a bit about the place where the event happens. It was during these touristic moments that I visited the Mangal das Garças and, inside of it, the Amazonian Navigation Memorial. There I saw an 'ubá', a type of canoe of native Brazilians. This canoe is carved in a single tree trunk, it does not use a keel. I observed that to make the ubá, it is necessary to remove the branches from the chosen tree; the tree trunk is dug, using a tool and fire; the external shape of the canoe is sculpted; the hull is turned upwards; the transforming trunk is slightly raised; a low fire is started under the future canoe; with the wood heated, the canoe is being stretched. This procedure fed my imagination and I tried to create musical gestures inspired by the process of creating the canoe. For example, the initial gesture of the piece was inspired by the image of the fire burning in the trunk that becomes the canoe, eventually releasing a spark; the transformation of the timbre (dolce to metallic) is a way to illustrate the vivid color of the flame. The combination between the aggressive sound of the tapping attack and the delicacy of the harmonics also refers to the fire, its softness and the crackling sounds. The sound of nails on the strings is like the sound of wood creaking and opening slowly. The central part evokes the ritualistic air of the 'ubá' construction process. I composed this piece just after coming back home from the Symposium.

Although the piece was recorded in 2014 for my compositions portfolio prepared for my Master thesis, its official debut took place on $2^{\text {nd }}$ September 2016, in EMESP's Zequinha de Abreu auditorium, São Paulo, with guitarist Fernando Aguera. The piece was performed again on $22^{\text {nd }}$ November 2018, at Paço da Liberdade, Curitiba, by guitarist Eric Moreira. In addition to 'Úba', I composed another piece inspired on my experience in Belém: 'Icamiabas in the mirror of the Moon', which is still unperformed. Both are part of the 'Belenenses' cycle. 


\section{Ubá}

Belenenses

Eduardo Frigatti 
申 um quarto de tom acima

qum quarto de tom abaixo

$\frac{1}{4} \nearrow$ ascender um quarto de tom, conforme a indicação.

$\frac{1}{4} \searrow$ atacar a nota um quarto de tom acima e descender, conforme a indicação.

- arrastar a unha sobre a corda

+ atacar a nota com a mão direita (M.D.) ou mão esquerda (M.E.) / (tapping) 
Scordatura

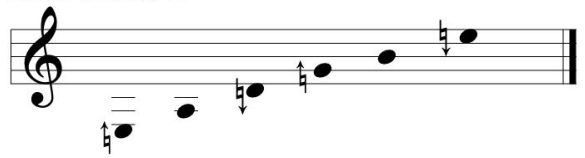

Ubá

Belenenses

Eduardo Frigatti

Calmo

São Paulo, julho de 2013.

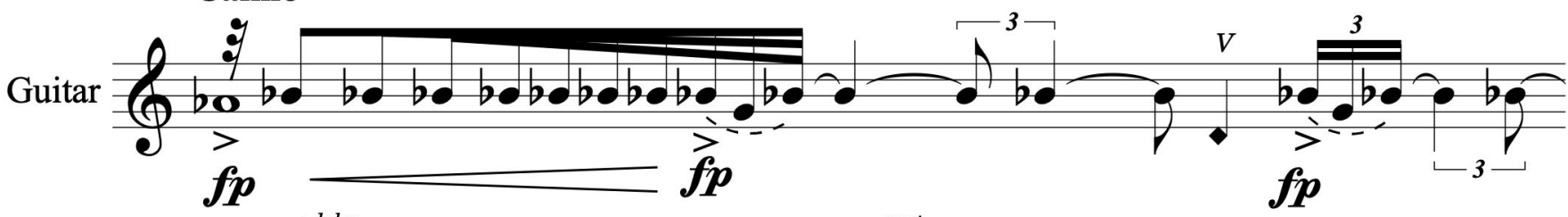

dolce
sul tasto a sul ponticello

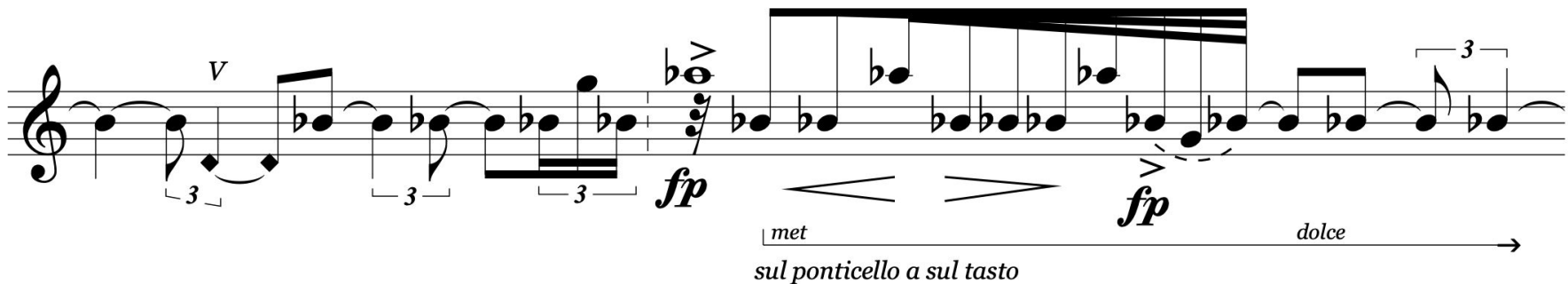

sul ponticello a sul tasto
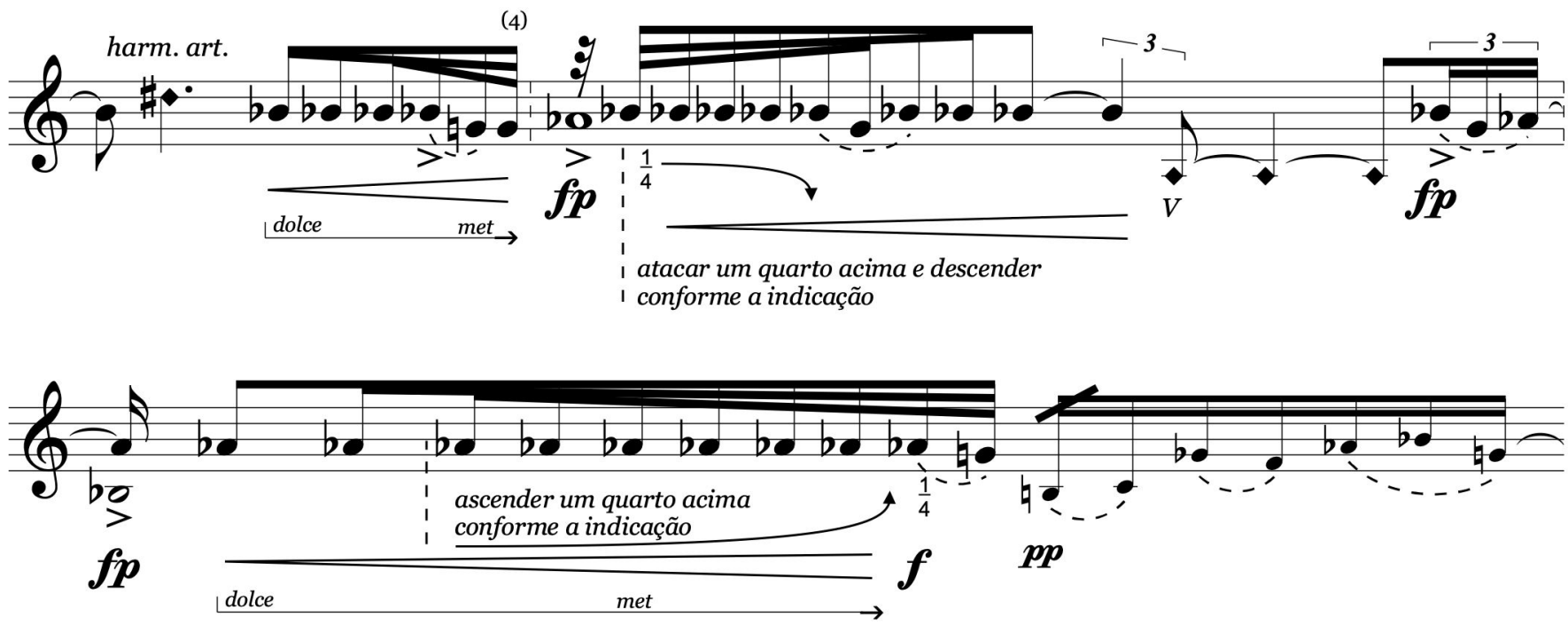

harm. art.
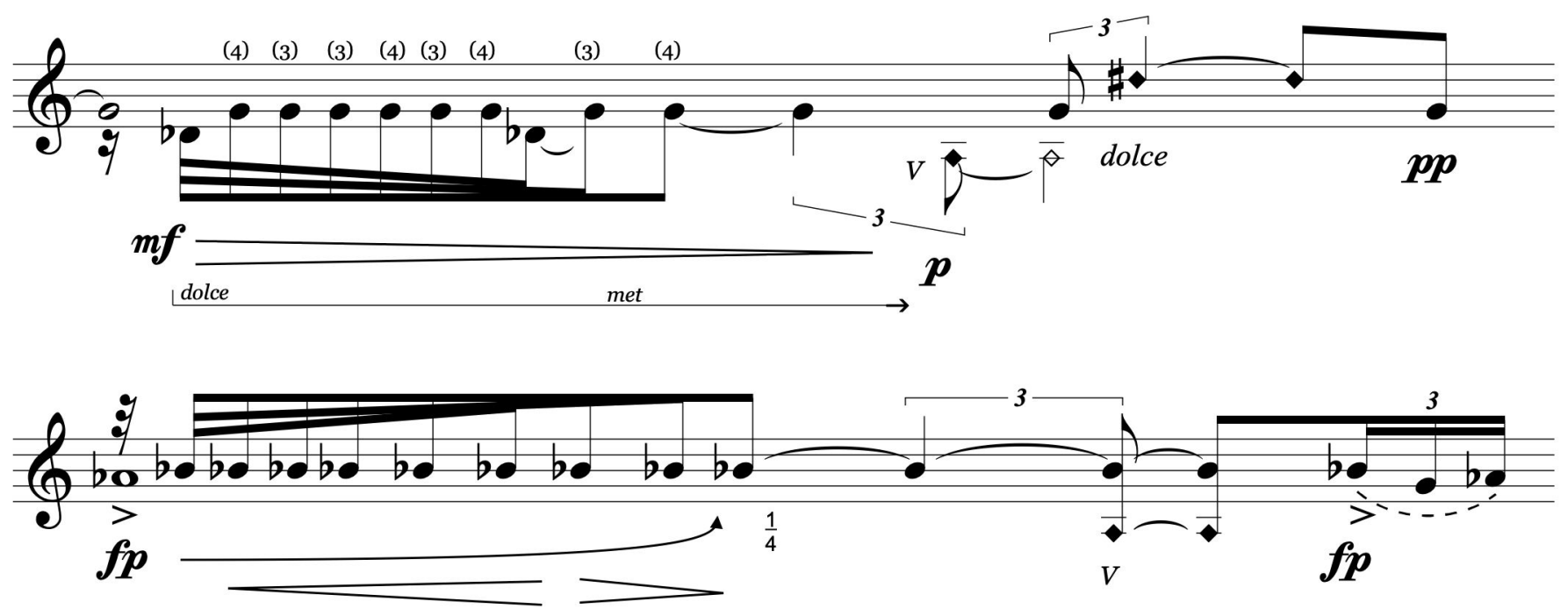
Ubá
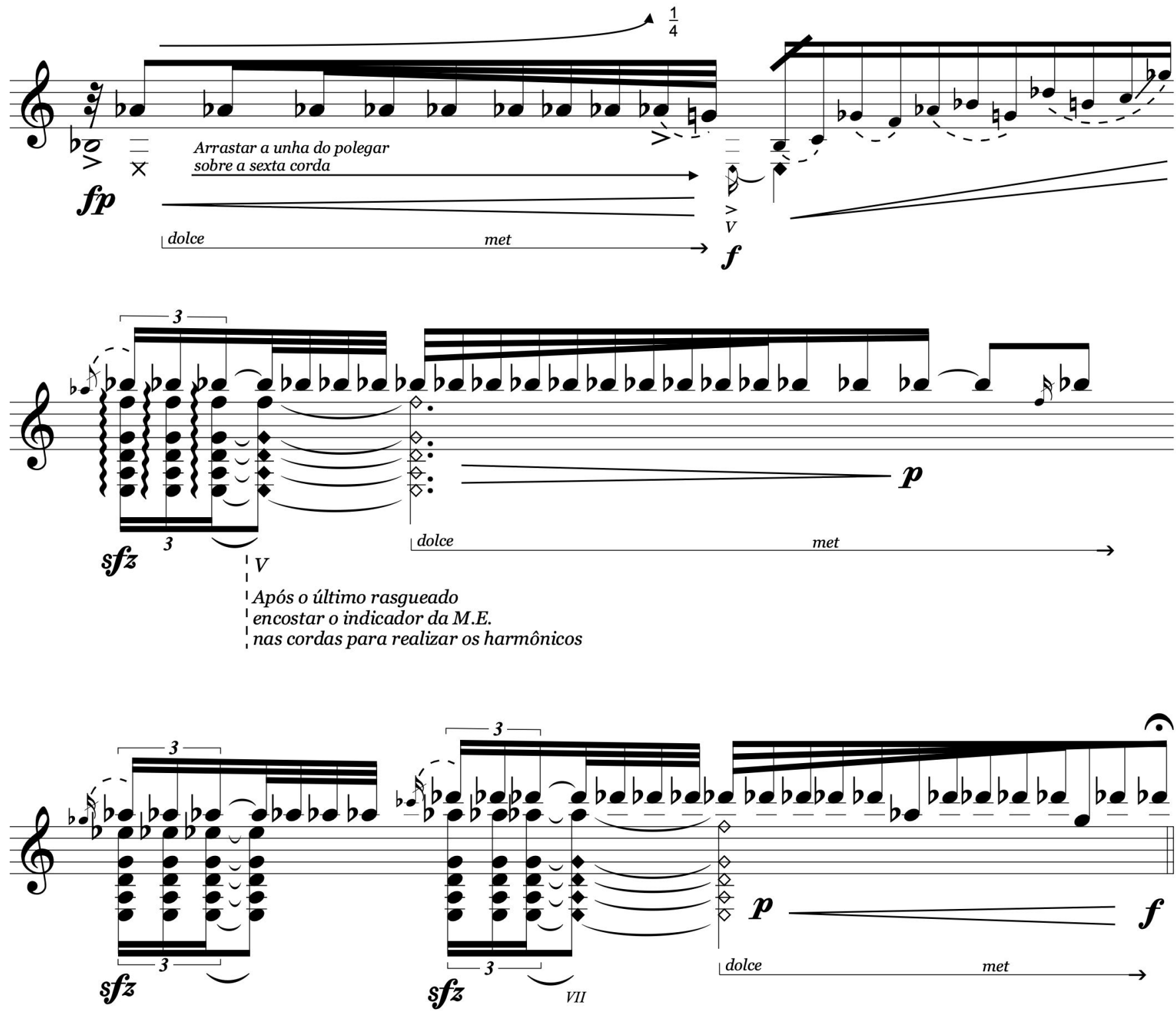

\section{Letárgico mas cantabile}

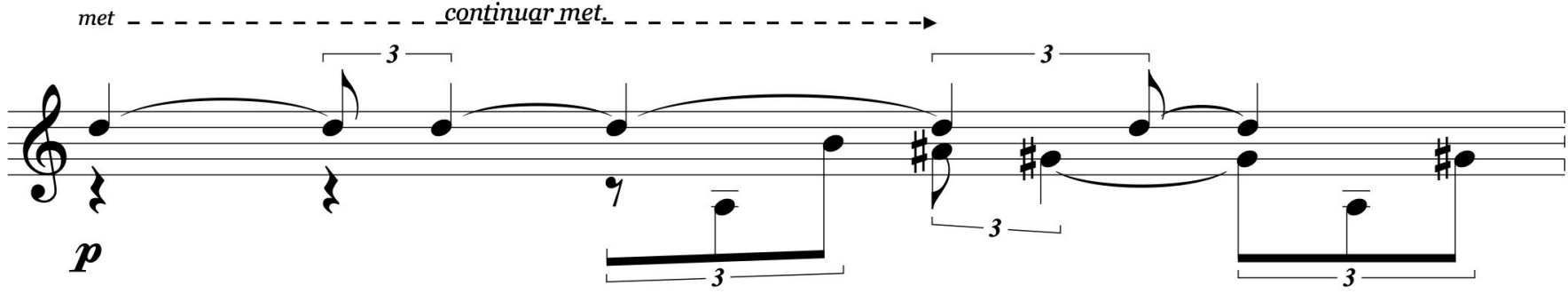

dolce _. . . . . _ continuar dolce _ . . . . . . . $\rightarrow$

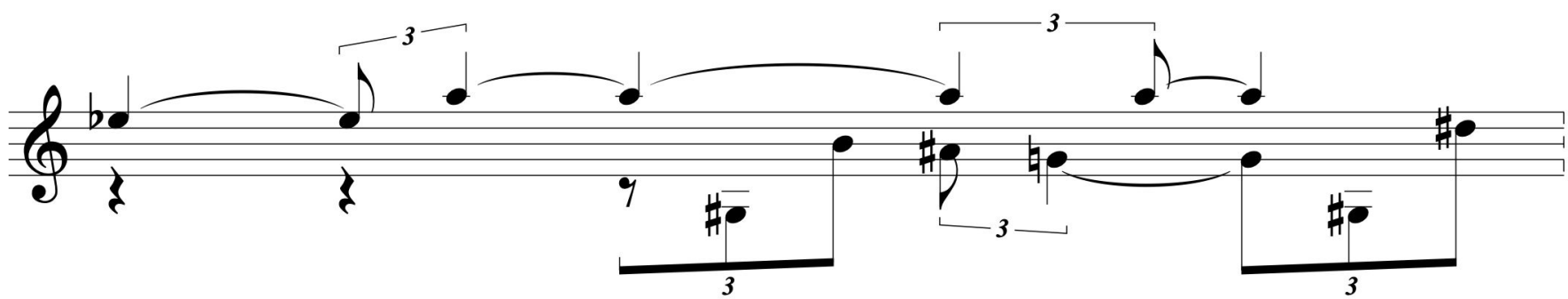



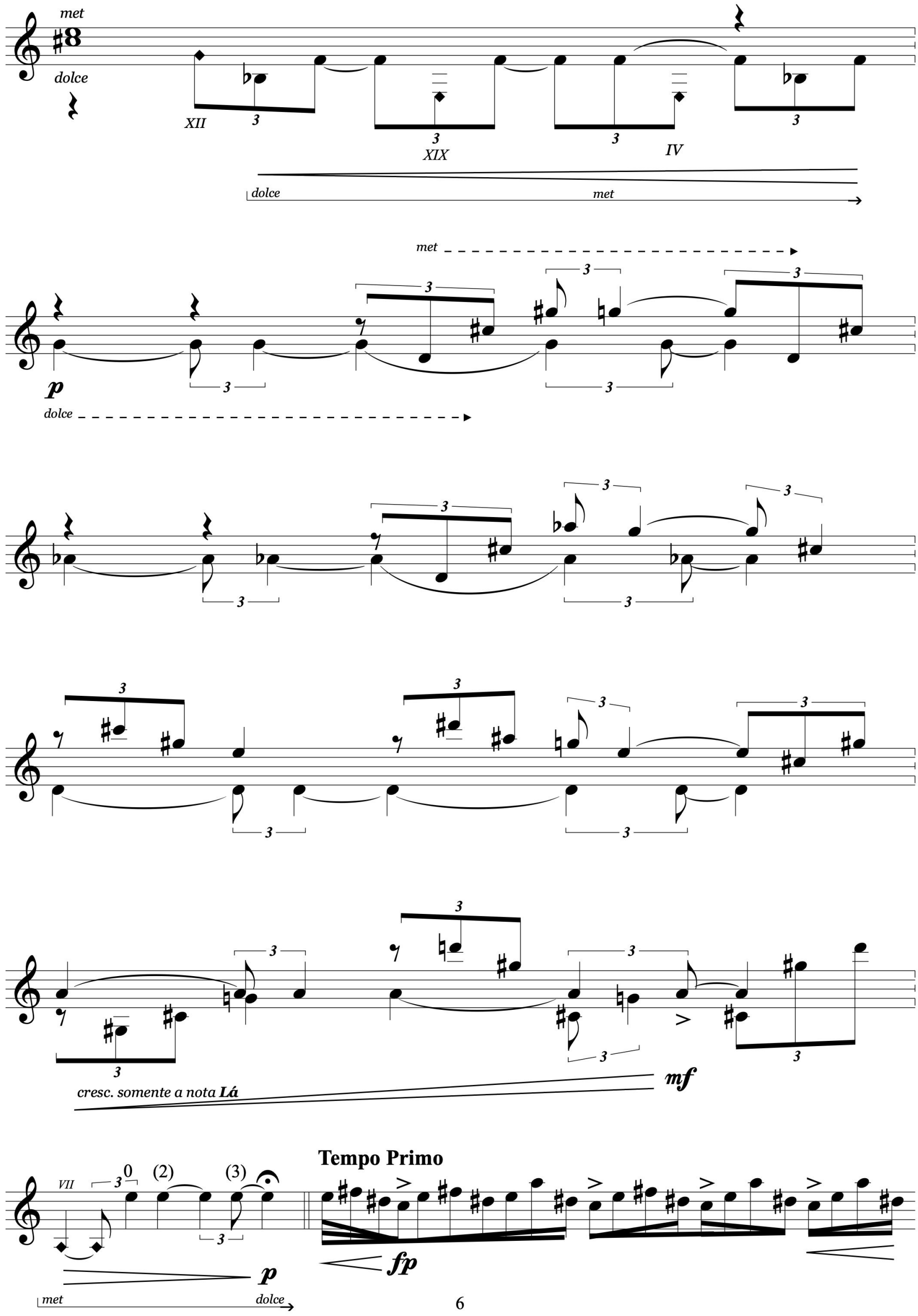
FRIGATTI, Eduardo. Ubá , Belenenses. Revista Vórtex, Curitiba, v.8, n.3, p. 1-8, 2020.

Ubá
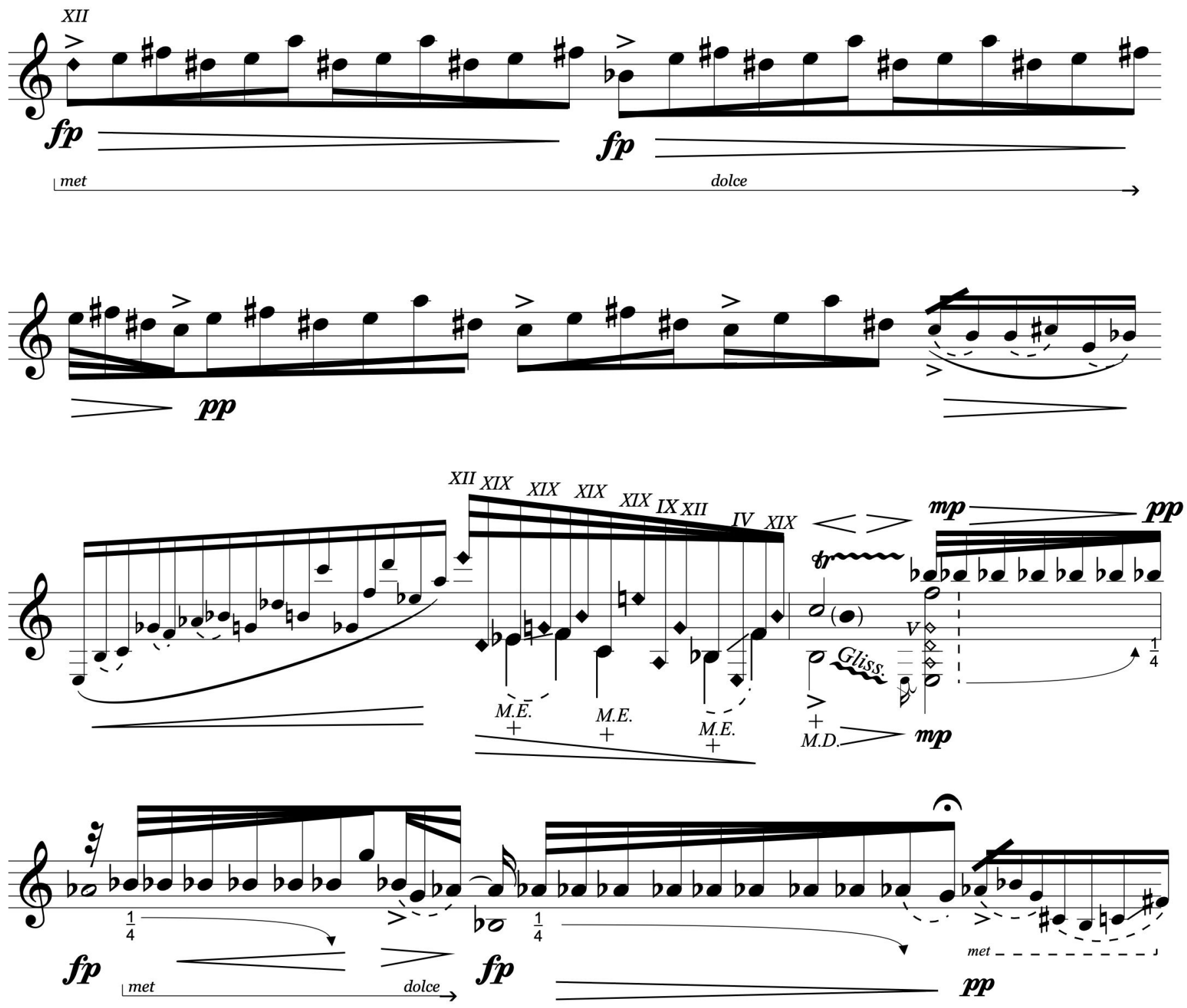

(4) (4)
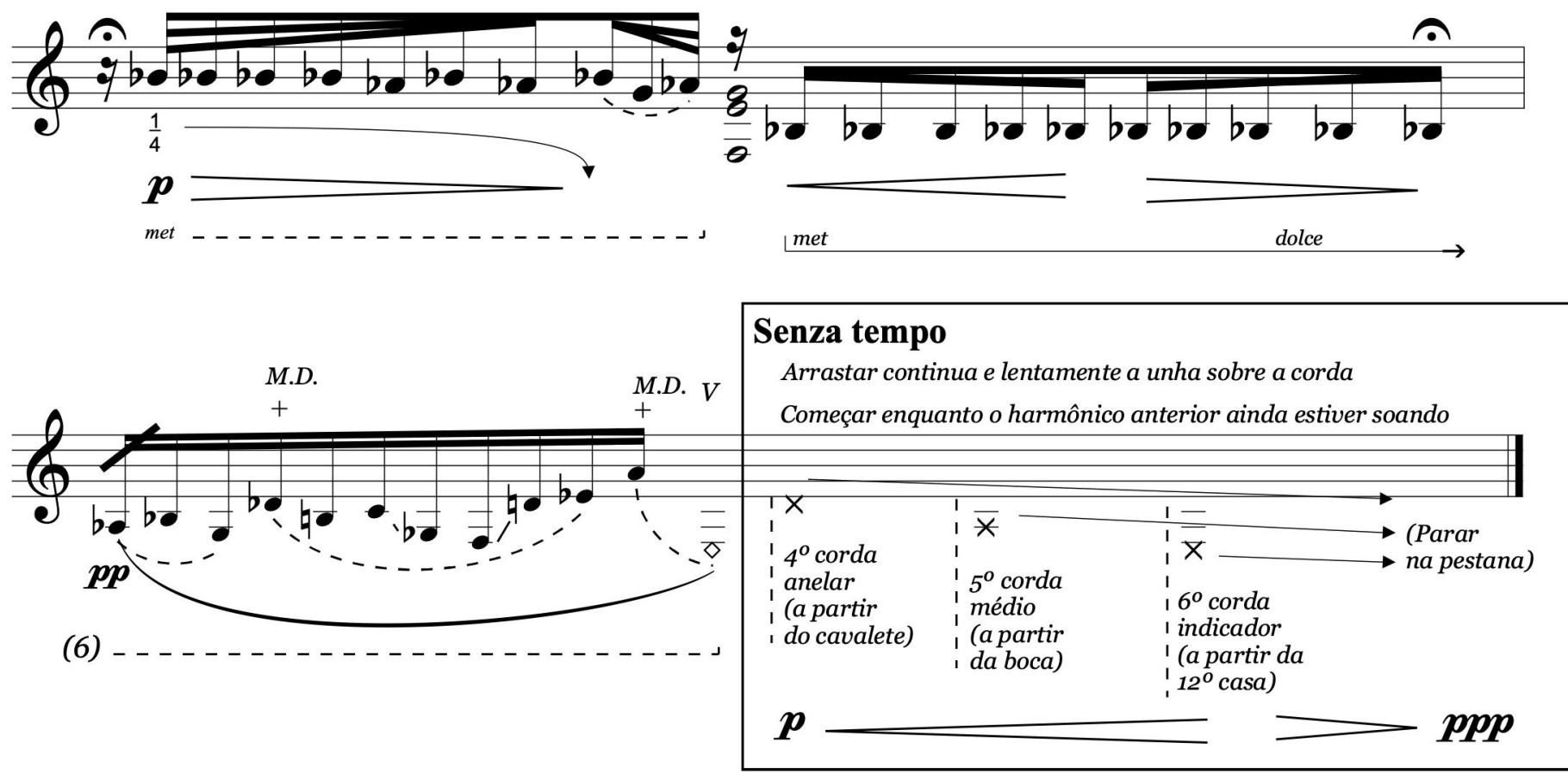